\title{
The price of power
}

The price of oil is hovering at around US $\$ 100$ a barrel, a psychologically powerful level that experts and analysts once discussed in purely theoretical terms. John Deutch, a chemistry professor at the Massachusetts Institute of Technology in Cambridge and former director of the US Central Intelligence Agency under President Clinton, gives his thoughts on the issue.

\section{What is the significance of $\$ 100$ oil?}

The rise in oil prices indicates the inevitable truth that we are using up low-cost energy reserves in the ground. We should expect that over time, on average, oil and gas prices will increase. That increase will cause three things to happen: less oil and gas will be consumed; there will be a shift from oil and gas to renewable energy sources; and, happily, new technologies will become more attractive. I'm quite optimistic.

\section{What is causing this price rise?}

Demand for oil and gas, especially from rapidly growing Asian economies such as India and China, is a real driver. I think that the International Energy Agency projects that oil consumption will go up from 80 or 90 million barrels per day worldwide to about 120 million barrels per day by 2030 . The fastest growth will be from Asian economies.

\section{Is $\$ \mathbf{1 0 0}$ oil here to stay?}

Energy experts know that prices fluctuate. Although I think it is perfectly possible that oil prices will decrease from the present level to as low as $\$ 40$ or $\$ 50$ per barrel, I don't think we will see it drop to $\$ 20$ again. And if you look at it on a decade-by-decade basis, the march of oil prices will be up, and gas prices too.

\section{Will prices ever get high enough to cause a global recession?}

Talented economists point out that oil is less of a major factor in world economy than it was 20 or 30 years ago. But it's certainly the case that as the price goes up, there will be adverse economic consequences for different countries, and some nations will suffer more than most. The small importing countries in Africa and the Caribbean, they will really suffer.

\section{Are we approaching a peak oil scenario?} Higher (and stable) prices open the economic window for new technologies. There is no [price] threshold; it is gradual. For example, biofuels from biomass are thought to cost \$40-50 per barrel when produced at a commercial scale; synthetic liquids from shale or coal cost perhaps $\$ 50-70$ per barrel.

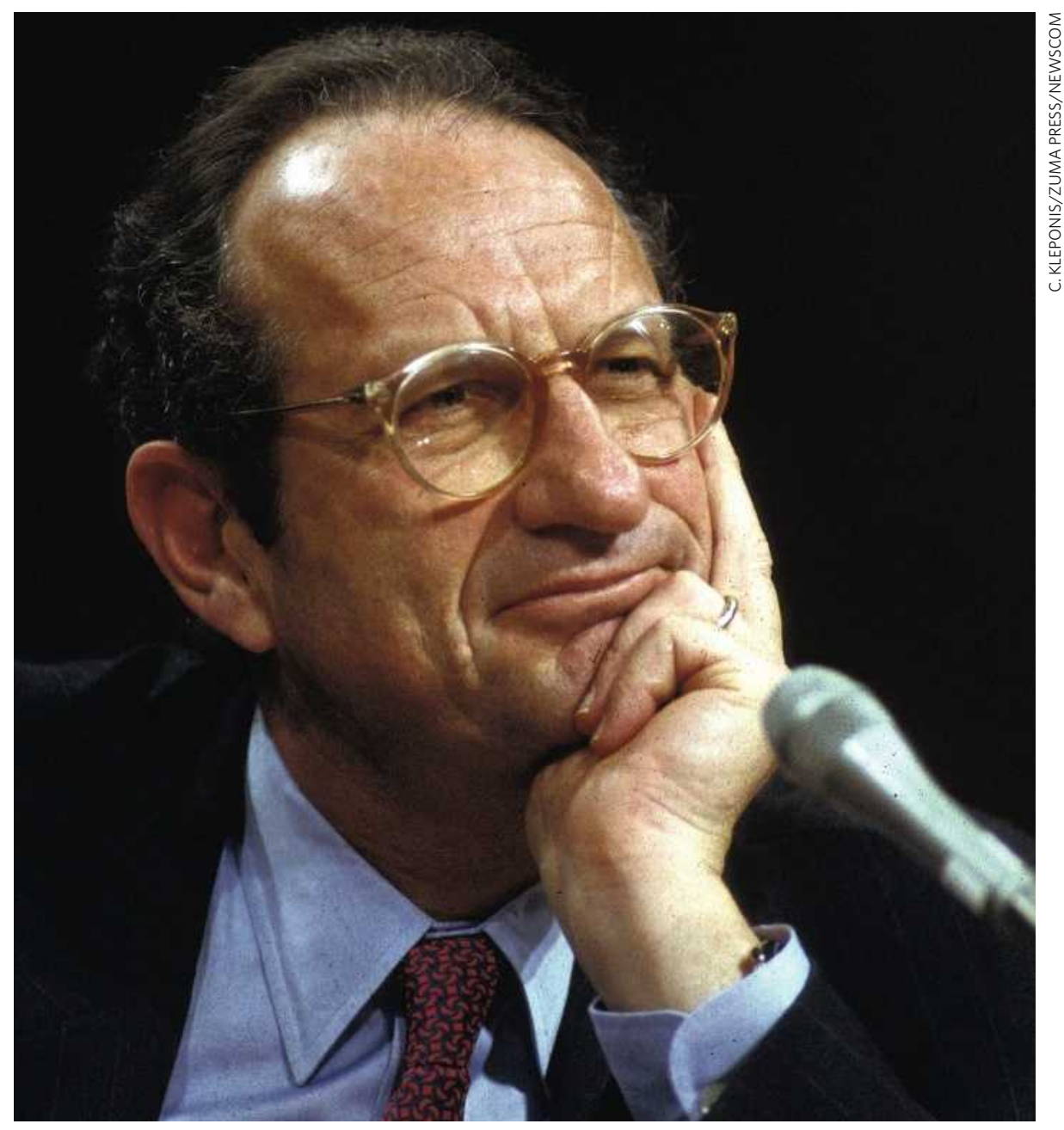

How much does US dependence on oil influence international diplomacy?

The energy-security consequences of oil and gas are very heavily dependent on the behaviour of markets and governments. The fact that we depend so much on oil from the Persian Gulf - from Saudi Arabia, Iraq, Iran and Kuwait - leads to questions about these nations' political stability and the role of terrorists. The fact that Iran is supplying 2.9 million barrels of oil per day to world oil markets certainly constrains the freedom of action that Europe and the United States have on other issues of importance, for example on how Iran is pursuing its clandestine nuclear-weapons programme, and on its activities in Iraq.
How critical is it that a carbon-pricing system be put in place if the economics of energy is to be changed?

I think the issue of a carbon-emissions price, either through a cap-and-trade system or a tax, has a more direct importance and urgency with respect to climate change. Of course it also affects the transition from a petroleum-based market, but those are two really quite separate problems. Environmental constraints must accompany the commercialization of any new technology. For example coalto-liquid fuels should be produced only if accompanied by carbon capture and sequestration.

Interview by Jeff Tollefson 